From Alexandria to Rome: Poetical Astronomy and Female

Psychology

\title{
Magda El-Nowieemy
}

Faculty of Arts, Alexandria University

\section{Abstract:}

It is admittedly acknowledged that ancient Alexandria contributed much knowledge to the field of astronomy. Consequently, this astronomical heritage was transmitted to Rome. Hence, the Roman poets of the Empire were working within an established tradition of astronomical knowledge. It seems that this tradition was much on the Roman poets' minds that they embedded this sort of knowledge in their poetical production.

In several mythological love stories that were treated by the Roman poets, it is noticeable that at the moments of crisis of female intensified passion, or torment by conflicting emotions, the poets give a prominent role in the love stories to the stars (their risings and settings) and to other astronomical elements (the first visibility of the new moon, etc.), while portraying the unspoken anguish, the intensity of the suffering, or the frenzy of the woman who is overcome by obsessive love.

Here we place this design of poetic thought within the Alexandrian tradition and explore the cumulative effects of the physical environment as a site for sustained poetic treatment. We cast light on comprehending the ideas of the Roman poets in the light of the increasing importance of astrophysics, experiencing a mythological feminine tragedy in cosmological terms.

\section{Keywords:}

Astronomy, astrology, cosmology, Hellenistic Alexandria, Roman poetry, Virgil's Aeneid, Ovid's Metamorphoses, feminine agony, Dido and Medea. 


\section{From Alexandria to Rome: Poetical Astronomy and Female Psychology}

\section{Introduction:}

Usually the study of women in classical antiquity includes their role in society, their role in the history of sexuality, and includes also discussions of gender, and the body. But my approach in the present paper differs drastically from this kind of scholarship on women in classical antiquity by using the lens of astronomy. With this shift of focus, I believe, we may conceive the integration of the female soul as a particular into the physical world. An overview on the role that astronomy and cosmological phenomena play for the woman, including the perceived fate of her, is given in the course of this paper.

In several mythological love stories that were treated by the Roman poets, it is noticeable that at the moments of crisis of female intensified passion, or torment by conflicting emotions, the poets give a prominent role in the love stories to the stars (their risings and settings) and to other astronomical elements (the first visibility of the new moon, etc.), while portraying the unspoken anguish, the intensity of the suffering, or the frenzy of the woman, who is overcome by obsessive love. It is believed that "the stars and poetry go together for the Romans". ${ }^{1}$ Most likely, the Alexandrian interest in combining poetry and astronomy, as exemplified in the Phaenomena of the Hellenistic poet Aratus of Soli in Cilicia (c. 315-c. 240 BC), and the epic poem Hermes of Eratosthenes of Cyrene (c. 276- c. $194 \mathrm{BC}){ }^{2}$ was transferred to Rome. ${ }^{3}$

\footnotetext{
1 - Gee 2001, 533; cf. Fox 2004.

2 - See Solmsen 1942, 199-200, 211-213.

3 - On the connections between literature and astronomy, see Lankford 2011, 307314; relevant to my discussion here, see Hardie 1989, 1-22.
} 


\section{Magda El-Nowieemy}

We are familiar with the union of astronomy and mathematics, astronomy and religion, astronomy and philosophy. ${ }^{4}$ We are also familiar with the role of the stars and constellations in Greek religion and Greek literature in respect of farming and sailing, and consequently we are familiar with the role of these activities in cultural heritage, or as it has been reported in other words "Astronomy is the Mother of Civilization". 5 But we are not familiar to the same extent with astronomy and female psychology in love. Astronomy which more usually keyed to those sciences, may be made the central focus of a love-story. The notion that stars, or other astronomical elements, and female psychology are connected may seem odd at a first glance. Nevertheless, we, as readers, may enjoy the knowledge of the connection between human female tragedy and the cosmos around, from human perspective.

I do not mean by the title of my paper "From Alexandria to Rome", to exclude the impact of the work done by Babylonians and Egyptians (despite the contradicting assertions concerning these two cultures in the field of astronomy), but my concern here is the immediate cultural context in which the Roman poems under discussion were produced, as the Alexandrian tradition was close in time and outlook to the Roman poets themselves. $^{6}$

4 - For the relation between the different sciences in antiquity, see Rihll 2002; cf. Cornford 1952.

5 - Moussas 2013a, 384-385.

6 - On the issue of the circulation of astronomical knowledge, see the "Introduction" by Steele to the 2016 edition, 1-4, and the papers contained there. 


\section{From Alexandria to Rome: Poetical Astronomy and Female Psychology}

The Roman poets' awareness of the famous Alexandrian scientists: Aristarchus of Samos (c.310-c.230 BC), Archimedes of Syracuse (c.287c.212 BC), Eratosthenes of Cyrene, and Apollonius of Perga (c.240-c.190 $\mathrm{BC})$, and their awareness of the advances of the Hellenistic knowledge of astronomy in particular, ${ }^{7}$ might profitably have been applied to these passages in question in their poetry.

If we look at the Roman poets' words with attention centered on astronomy, several points stand out concerning the significant psychological sensitivity, which is essential to a fuller understanding of those very passages. This invites the reader to reflect at length on the underlying meaning of the passages of feminine agony.

This paper does not pretend to tackle astronomical theories or planetary phenomena per se. It is an attempt to locate certain correlating ideas in the history of ancient astronomy, not as astronomy proper, but in the tradition of cosmological speculation. Consequently, it is not a strictly scientific treatment of cosmological phenomena. One merit of the present treatment, I may suppose, is to raise certain questions: Was the frequentative mention of the stars, or of any astronomical and cosmological aspects, required to depict the heroine's agony, her sleeplessness, and her tragedy in general? Was the appearance of the stars in particular, and astronomical phenomena in general, intended to make the reader engage in the perception of cosmological reality or to enhance the perception of this reality? Was there in the Roman poets' conception a connection between the cosmos and the temperament and fate of a female in love? Was it based on philosophical considerations? Or was it a mere poetized vision of the heritage of

7 - See North 1994, 85-119; Evans 1998, 67-73, 259-62. 


\section{Magda El-Nowieemy}

astronomy? Was it the poets' perception of the reality of the female soul in its connection to the cosmos? Or was it their perception of the cosmos animated by female soul?

The aim in this paper is threefold: First: to place this design of poetic thought within the Alexandrian tradition that is essential to a fuller understanding of the passages under discussion, on the basis of either familiarity with the topic or competence in the treatment. Second: to explore the cumulative effects of the physical environment as a site for sustained poetic treatment, above and beyond what we would normally expect from poets. Third: to cast a light on how we might understand the ideas of the Roman poets in the light of the increasing importance of astrophysics. That is to say, how we are experiencing a mythological feminine tragedy in cosmological terms.

\section{The Roman Poets in the Context of the Previous Astronomical Tradition:}

The Roman poets' astronomical information is derived naturally from the original Greek ideas about some astronomical phenomena: firstly the early Greek cosmology and natural philosophy, ${ }^{8}$ then Greek astronomy proper. The Greek philosophical and scientific tradition established rational constructs for understanding the cosmos and its phenomena through rational observations. Greek attempts to offer natural explanations of the sky are

\footnotetext{
8 - See Kahn 1970; Theodossiou et al. 2011; Hannah 2015.
} 


\section{From Alexandria to Rome: Poetical Astronomy and Female Psychology}

noticeably recorded. ${ }^{9}$ Then, in the changing intellectual climate of Alexandria, more accurate observations were achieved. ${ }^{10}$

Alexandria developed new knowledge in astronomy, as well as in other sciences, ${ }^{11}$ which it is not my purpose here to treat in detail, and of which there exist many remarkable studies as exemplified in the notes. ${ }^{12}$ Alexandrian scientists improved the previous knowledge of understanding the natural world, in which Greece presented a key contribution. Hellenistic Alexandria was a standard for centuries in astronomy and other sciences. Up till now historians of sciences have awarded a due emphasis to Hellenistic Alexandria in this concern. ${ }^{13}$

When Alexandria, as a native town of natural sciences, became a part of the Roman Empire, a network of astronomical understanding was born at Rome. Besides the impact of the Alexandrian observational astronomy on the Romans, the ideas of the Stoics were more appealing to the Romans. ${ }^{14}$ In such a cultural context, the Roman poets tackled astronomical phenomena in their poems. We may call it a poetic rumination

9 - See Goldstein and Bowen 1983; Moussas 2013b, 76-79; Moussas 2013c; Spyridis et al. 2019.

10 - See, for example, Irby-Massie and Keyser 2002, 47-81; Deming 2010; Bowen 2020, 284-293.

11 - In the words of Klein 1974, 224: "Alexandria was a highly literate metropolis in which the rich mythological traditions of the past were yielding more and more to the scientific enquiry of an Aristarchus, a Heron and a Herophilus".

12 - See notes 7,10 and 13.

13 - See, for example, Berrey 2017; Bowen and Rochberg 2020.

14- For Stoicism and astronomy, see Jones 2003, 328-344. Gill 2003, 33-58, esp. 34, argues that "The Julio-Claudian era (From Augustus to Nero) was, in broad terms, a positive context for Stoic and other philosophical activity." For the influence that Stoicism had on Roman literature, see under the heading of "Stoicism and Roman Poetry" by Gill, 56-58. For the combination of poetic artistry with philosophical doctrines in Augustan poetry, see DeLacy 1947. 


\section{Magda El-Nowieemy}

on astronomy, as if the Roman poets were emphasizing the validity of the considerable legacy left for them, as well as for later eras, by Hellenistic Alexandria.

\section{Virgil's Dido, Ovid's Medea and Astronomical Phenomena:}

Sometimes the Roman poets dwelled much on the astronomical phenomena, and sometimes mention was made only in passing by them. What sort of familiarity did their readers have with this sort of astronomical knowledge?

The myths of Dido in the Aeneid of Virgil (70-19 BC), and Medea in the Metamorphoses of Ovid (43BC-AD 17) may fairly be taken as representatives.

In Book 4 of Virgil's Aeneid, lies the poet's great strength in portraying emotions in the moving story of Dido and Aeneas. Virgil admirably raises the affinity with astronomical phenomena without exploring its full implications, leaving it open-ended to his readers, who were supposed to be docti, i.e. "cultured and educated".

The basic elements of early astronomy: the sun, the moon, and the stars, figure prominently in the Dido story. They are the physical dimensions of the love story. The changing position of the risings and settings of the sun and the moon on the horizon is quite noticeable as a background of love and agony at their utmost. We should put in mind that the Aeneid is an epic of both mythological narrative and philosophical 


\section{From Alexandria to Rome: Poetical Astronomy and Female Psychology}

reflection. ${ }^{15}$ The mythology of the past in the hands of Virgil was yielding more and more to the scientific tradition of Alexandria.

From the first encounter, Dido felt a very real admiration and affection for Aeneas. The poet dwells on the intensity of Dido's feelings, as her passion grows and is nourished by her. ${ }^{16}$ In order to introduce the reader to Dido's first speech to her sister and confidant, Anna, confessing her love for Aeneas, Virgil started with the integration between love and cosmos, depending on the cosmic events of day and night:

At regina gravi iamdudum saucia cura vulnus alit venis et caeco carpitur igni. multa viri virtus animo multusque recursat gentis honos; haerent infixi pectore vultus verbaque, nec placidam membris dat cura quietem.

(Aen. 4. 1-5)

"Yet the queen now for a long time has been wounded with grievous love, nourishes the wound with her veins and is consumed with hidden fire. Many a virtue of the hero and the honour of his race are recurring to her mind; his looks and words remained imprinted in her heart, love does not allow her members sweet rest."

Immediately after this, the poet turns to the daily alteration of night and day:

Postera Phoebea lustrabat lampade terras umentemque Aurora polo dimoverat umbram, cum sic unanimam adloquitur male sana sororem:

(Aen. 4. 6-8)

15 - For a good study of philosophy in Virgil, see Farrell 2014, 61-90.
16 - See Camps 1969, 31-35; Fantham 1975, 1-10. 


\section{Magda El-Nowieemy}

"The next day's Aurora [Dawn] was lightening the earth with the torch of Phoebus[the Sun], and had removed from the sky the dewy shade, when [Dido], love-sick, spoke thus to her sympathizing sister:"

It is important to recognize that the Dawn, the Sun, are mentioned not only as indicators of the time for love-confessions, but also as weaved in the poet's constructions of emotions.

Here, we can see the circularity of time in the "psychological cosmos". The poet is depicting an emotional process by the aid of natural phenomena. The dark night is now over. The setting of the mythical fullness of the sunrise "seems to set a happy mood". ${ }^{17}$ But this, as far as I can see it, is only on the surface. The daylight is actually not cheerful, as one might naturally expect it to be. ${ }^{18}$ The daylight does not dissipate the gloomy forebodings of the preceding night. It introduces "a new frenzy". ${ }^{19}$

When the poet portrays Dido's agonized love, he again weaves the cosmos in his portrayal:

Uritur infelix Dido totaque vagatur

Urbe furens,

Nunc media Aenean secum per moenia ducit

Sidoniasque ostentat opes urbemque paratam;

incipit effari, mediaque in voce resistit;

nunc eadem labente die convivia quaerit,

Iliacosque iterum demens audire labores

17 - Segal 2000, 91.

18 - More stimulating to my argument here, though with completely different end in mind, see Syropoulos 2010.

19 - Otis $1963,80,86$. 
exposcit pendetque iterum narrantis ab ore.

Post ubi digressi, lumenque obscura vicissim

Luna premit suadentque cadentia sidera somnos,

Sola domo maeret vacua stratisque relictis

Incubat. Illum absens absentem auditque videtque,

$$
\text { (Aen., 4. 68-9; 74-83) }
$$

"Wretched Dido is inflamed, and wanders in the whole city in frenzy.....Now through the middle of the walls [of the city] she leads Aeneas with her and displays [to him] the Sidonian wealth and the city under construction. She begins to speak, and breaks off in the middle of her speech. Now, as the day passes, she seeks the same banquets, again being mad she requests to hear the troubles of Ilium [from her lover] and again hangs on the speaker's lips. Afterwards when they have departed, and the dark Luna[goddess of the Moon] in turn conceals her light, and the falling stars invite sleep, she mourns alone in her empty palace, and leans in the deserted bed. Although he was absent, she both hears him and sees him while absent."

The waning and waxing of the moon are referred to here as a signal for timing her love agony. It is as if Dido's everyday life were linked inextricably to cosmic events.

If the appearance of stars, the risings and settings of the sun and the moon are to be interpreted in such a way, how are we to understand the references to weather phenomena?

The sky continues to play a role in Dido's love story, with the weather signs, the rain-clouds, and showers mixed with hail, amid thunder 


\section{Magda El-Nowieemy}

and lightning. These were a sort of celestial omens. The poet's interest was centered on the female love as well as on the cosmos. Nature exhibits certain patterns that could be followed within the story, as it is a natural part of the human condition to follow those patterns in nature. The love-couple, Dido and Aeneas, sought shelter at a cave. The poet even goes so far as to make the sky attest the liaison of the couple, and even connive at their union by flaring lightning. Later on in the story, when Dido, as a woman abandoned in love, decided, out of despair, to take her own life, even "when she is about to die, she calls upon the gods and the stars that were aware of her doom to witness":

Testatur moritura deos et conscia fati

Sidera; ...

(Aen. 4. 519-20)

The coincident risings of the stars in the heavens are employed by the poet. At the climax of Dido's agony, "it was night" (nox erat, 522), the poet describes "when the stars are rolling in the middle of their gliding course" (cum medio volvuntur sidera lapsu, 524). This is as if there were some sort of "cosmic sympathy".

It is worth mentioning in this context that somewhere else in his poetry, Virgil names the stars (Georgics, I. 137-138: Pleiades, Hyades, and Arctos). ${ }^{20}$

Virgil is interested in the psychology and physiology of anger. ${ }^{21}$ In her long soliloquy before her suicide, Dido, in her angry vengeance, addresses both the Sun and Hecate (the goddess associated with night, the moon, witchcraft and magic), cursing Aeneas who deserted her. With

\footnotetext{
${ }^{20}$-Cf. Homer, Iliad, 18. 486-489; for more details, see O'Hara 1992.

21 - See Wright 1997, 169.
} 


\section{From Alexandria to Rome: Poetical Astronomy and Female Psychology}

perfect clarity this reflects both the Alexandrian interest in the long-drawn emotions of soliloquy, ${ }^{22}$ and the Alexandrian interest in the goddess of night and the moon. All this was enwrapped with emotional utterances.

At the end of Book 4, the agony of Dido's death is prolonged till she gazed upward and realized the light at the sky:

$$
\text { oculisque errantibus alto }
$$

Quaesivit caelo lucem ingemuitque reperta.

$$
\text { (Aen. 4. 691-2) }
$$

"With wandering eyes she sought light in the high sky, and she gave a sigh when she found it".

This reminds us of the original notion behind being a "human", anthropos, in Greek conception, "the one who looks up, the one who observes the sky". ${ }^{23}$ Here, furthermore, the poet explores, in particular, the psychological and spiritual effects of the cosmos. Dido's tragic story ends with her life vanishing into the winds. To the last moment the physical environment is strongly present.

Some questions may immediately leap to mind: Is it the physical characterization of the soul related to the philosophical psychology of the Greek philosopher Heraclitus (fl. $6^{\text {th }}$ century BC), one may say? ${ }^{24}$ Is it a metaphysical framework that contains a tragic love story? Does this correspond to the biological side of the Stoic cosmology, as the Stoic philosopher Zeno of Citium (c. 334-c. 262 BC) believed the cosmos to be a living being? ${ }^{25}$ Or is it a mere staring at the sky, known to all the cultures with an awareness of the heavens? Is Dido seeking the full spectacle of the

\footnotetext{
22 - See Baldwin 1959, 218.

23 - Moussas 2013b, 77; Moussas 2013c, 129.

24 - For the philosophical psychology of Heraclitus, see Betegh 2007.

25 - On the physicalism of the Stoics, see Annas 1992, 37-85, cf. Hahm 1977.
} 


\section{Magda El-Nowieemy}

starry heavens? Or is she seeking celestial predictive omens? All these questions are open to speculation.

Furthermore, let us turn to another Roman poet. It is Ovid, who explores in particular the psychological and spiritual effects of astronomical phenomena on the female psychology. In the seventh book of his masterpiece, the Metamorphoses, he treats the story of Medea, who falls in love with Jason. Medea embodies the destructive power of love. When she is newly aware of her love, Ovid describes her by the following words:

concipit interea validos Aeetias ignes

et luctata diu, postquam ratione furorem

vincere non poterat, .....

(Ov., Met. 7. 9-11)

"The daughter of Aeetes [Medea] conceived a strong passion of love and she struggled long [against it], when she could not overcome her mad desire by reason,...".

At this stage, Medea's love was un-declared, and one-sided. In her monologue, she aspired to be Jason's wife. In such an aspiration the heaven and the stars were prominent:

..........................quo coniuge felix

et dis cara ferar et vertice sidera tangam.

$$
\text { (Ov., Met. 7. 60-1) }
$$

"... with him as my husband, I shall be fortunate and shall be reckoned dear to the gods, and with my head I shall touch the stars". 


\section{From Alexandria to Rome: Poetical Astronomy and Female Psychology}

This expression of "touching the stars" is characteristic of the Roman poets' style of thought when talking about their fame. ${ }^{26}$ Although this example is quite slightly peripheral, but still I include it, as the repeated references to the stars are connotative. This shows that astronomical elements were an embedded part of the Roman poets' culture. These elements offer themselves, so it seems to me, as an inviting context for female psychology.

When Ovid describes the magical activities of Medea, he mixes astronomical phenomena with astrology, "the anthropo-psychic view of causation directed at the sky": ${ }^{27}$

Tres aberant noctes, ut cornua tota coirent

efficerentque orbem, postquam plenissima fulsit

et solida terras spectavit imagine luna,

fertque vagos mediae per muta silentia noctis incomitata gradus...........

(Ov. Met., 7. 179-81; 184-5)

"Three nights were wanting, till the horns [of the moon] would come fully together and form a circle, when the moon shined at its fullest, and looked on earth in its complete appearance .....and through the still silence of midnight [Medea] unaccompanied directed her unsteady steps...."

26 - See, for example, Hor. Od. I.1. 35-36.

27 - Irby-Massie and Keyser 2002, 82. 


\section{Magda El-Nowieemy}

So, Medea in a way or another was like sailors and farmers, who spent their lives looking at the sky with its stars, trying to figure out their predictive aspects and meanings.

It was the case throughout antiquity that it was difficult to distinguish between astronomy and astrology. ${ }^{28}$ In the Hellenistic age, astronomy was adopted by magicians as well as by Stoic philosophers and mystery religions. But in Alexandria, the "center of ancient astrology", there was "a search for better astronomical methods" for astrology. ${ }^{29}$ From Alexandria, astrology enjoyed ascendency in the Hellenistic world. ${ }^{30}$

Ovid continues to describe the stillness of the universe, and then he adds:

sidera sola micant; (188) "the stars alone sparkled", in the sky.

Medea prays to the universal elements, which have affinity with magic to help her:

'Nox' ait 'arcanis fidissima, quaeque diurnis

aurea cum luna succeditis ignibus astra,

tuque triceps Hecate, quae coeptis conscia nostris

adiutrixque venis cantusque artisque magorum,

(Ov. Met. 7. 192-5)

"O night, she says, most trusty to my secrets, and you golden stars, who, with the moon, succeed the brightness of the day, and you triple-headed [goddess] Hecate, who is cognizant of my undertakings, and you come as an assistant to my incantations and arts of magic,"

\footnotetext{
28 - See Rihll 1999, 62; cf. Jones 1994, 38-39.

29 - Neugebauer 1975, 3-5.

30 - For astrology in the Hellenistic era, see Irby-Massie and Keyser 2002, 82-112.
} 


\section{From Alexandria to Rome: Poetical Astronomy and Female Psychology}

It was quite natural that with the transition to the Hellenistic age, the role of the moon goddess became more prominent in magical rites and astrology. This tradition naturally reached Rome.

Medea also prays to all the elements of nature to help her in her magic. In this astrological scenes related with magic, it is quite natural to find the moon and the stars playing a prominent role. Ovid here is incorporating ideas of personal destiny into astrology. The female here seems to be incorporated in astrological history, which is a branch of celestial divination.

From these, and many other passages that might be quoted from Latin poetry, we can trace the persistence of astronomy in the Roman mind. We cannot consider it a mere flight of fancy on the poets' part. Such poems, therefore, bear not only on the prominences of the visible cosmos, but also explore the interior world of the female soul.

\section{Conclusion:}

The Roman poets, mentioned here, were not astronomical writers; rather they described cosmological views, and sometimes developed a system of astronomy or astrology of their own, treated in a poetic context. Astronomy provoked a varied and a deep reaction in them. It became the psychological environment for their mythological love stories. Although this is a poetic handling of scientific themes, but this is not a matter of poetical technique or flight of fancy. There is more to be said about the richness of the scientific tradition available to the Romans. More importantly, the advances in natural science, and the comprehensiveness of conceiving the cosmos as then understood apparently appealed to the taste of their Roman contemporaries. 


\section{Magda El-Nowieemy}

Most of the astronomical references in their poems may not be distinguished individually, but taken together they have a cumulative effect that reflects what was in the Roman poets' minds and how they kept them in our minds and before us throughout. The associations of astronomy with literature were shown to be not random, and so the relation between humans and nature. These references reveal alertness on the Roman poets' part to both astronomy and astrology, which could by no means be negligible, but rather deeply rooted as the result of a long tradition based on fundamental assumptions that shaped the development and transmission of Greek Hellenistic science.

It could not be safely said that the Roman poets were simply following in the footsteps of a Homer or a Hesiod, because Greek astronomy in the time of these two Greek poets was basically still primitive and related to sailing and farming. ${ }^{31}$ But we may say that it was Alexandria which exercised a great impact on the Roman poets in this concern. Although the prominence of the gods of the sun and moon was connected with ancient religions, the transition to the Hellenistic age enhanced the role of these gods, especially the moon and night goddess Hecate, who played a greater role in magical rites and astrology.

Undoubtedly, as I may assume, with the impact of the Alexandrian astronomical heritage on the Roman mind, the Roman poets' cosmological views developed a sort of distinctiveness. It seems that the Roman poets had the sort of background astronomical information, especially that such poems were most likely not produced for the masses but for the educated and intellectual circles.

31 - See Hannah 2005, 18-27. 


\section{From Alexandria to Rome: Poetical Astronomy and Female Psychology}

Astronomy has always been vital in the history of cultures. Behind Roman poetry is the tradition of Alexandrian astronomy, familiar to anyone at the time with a good general knowledge and education. The abovementioned poets were Romans with a great concern for Alexandria, not only in the literary field, but also in the scientific.

Whatever our understanding of the implications of what the Roman poets wrote, this sort of writings brings to mind the anticipation of modern "philosophy of psychology", and "cosmobiology". Can such sciences have their roots in ancient writings including poetical astronomy besides others? Or can the ancient writings including poetical astronomy be interpreted by the lens of these modern sciences? They might be both ways, a two-way process. The study of the alliance of poetical astronomy and female psychology might be an essential step forward in our progress toward better understanding of astronomy in ancient cultures. One is led to the further conclusion that Latin poetry is a good indication of the high esteem astronomy enjoyed in the ancient world.

\section{Acknowledgements:}

*The present paper is a modified and expanded version of an earlier unpublished paper read at the Athens 2013 SEAC Conference.

I should like to express sincerely and gratefully my profound appreciation to the University of Alexandria which gave me the opportunity over and again to participate in international conferences that greatly developed my academic career.

With feelings of sincere gratitude I would like full-heartedly to thank Professor Xenophon Moussas for being a treasured source of inspiration in writing this paper, and in my concern with cultural astronomy. I 


\section{Magda El-Nowieemy}

acknowledge my indebtedness to the generous support I have enjoyed from him. I am particularly indebted to him for inspiring me how to read ancient literary texts with careful attention to scientific aspects and issues, with this inspiration I have beneficially continued with my students. Without his sincere encouragement, I would not have been able to continue in this trend. Last, but by no means least, a special word of thanks and appreciation is owed to Professor Ioannis Liritzis for his support and stimulating encouragement at various stages. He generously communicated to me his insightful sense of cultural heritage, and his ideas that ancient texts need to be seen under another light and in other dimensions. My thanks go to him for reading the final draft of this paper and offering useful suggestions as well as encouragement. I am alone responsible for its opinions, and all remaining faults are my own. 


\section{Bibliography}

\section{Text Editions:}

- Horace. 2012. Odes. Book I. Ed. with commentary by Roland Mayer. Cambridge: Cambridge University Press.

- Ovid. 1977. P. Ovidii Nasonis Metamorphoses. W. S. Anderson (ed.), Leipzig: Teubner.

- Virgil.1999. Eclogues, Georgics, Aeneid I-VI. Trans. H. R. Fairclough, Loeb Classical Library, Cambridge, MA and London: Harvard University Press.

\section{References:}

- Annas, Julia. 1992. Hellenistic Philosophy of Mind. Berkeley: University of California Press.

- Baldwin, Charles. 1959. Ancient Rhetoric and Poetic. Gloucester, Mass: Peter Smith.

- Berrey, Marquis. 2017. Hellenistic Science at Court. Berlin: De Gruyter.

- Betegh, Gabor. 2007. "On the Physical Aspect of Heraclitus' Psychology." Phronesis 52. 1: 3-32.

- Bowen, Alan. C. and Rochberg, Francesca (eds.). 2020. Hellenistic Astronomy: The Science in Its Contexts. Leiden and Boston: Brill.

- Bowen, Alan. C. 2020. "Issues in Greco-Roman Astronomy of the Hellenistic Period." In Hellenistic Astronomy: The Science in Its Contexts. Alan C. Bowen and Francesca Rochberg (eds.). Leiden and Boston: Brill. 284-293. 


\section{Magda El-Nowieemy}

- Camps, W. A.1969. An Introduction to Virgil's Aeneid. Oxford: Oxford University Press.

- Cornford, F. M.1952. Principium Sapientiae: The Origins of Greek Philosophical Thought. Cambridge: Cambridge University Press.

- DeLacy, Philip.1947. "Philosophical Doctrine and Poetic Technique in Ovid." CJ 43. 3: 153-161.

- Deming, David . 2010. Science and Technology in World History, Vol. 1: The Ancient World and Classical Civilization. North Carolina and London: McFarland and Company.

- Evans, James.1998. The History and Practice of Ancient Astronomy. Oxford: Oxford University Press.

- Fantham, Elaine. 1975. "Virgil's Dido and Seneca's Tragic Heroines." G \& $R$ 32: 1-10.

- Farrell, Joseph. 2014. "Philosophy in Virgil." In The Philosophizing Muse:

The Influence of Greek Philosophy on Roman Poetry. Myrto Garani and David Konstan (eds.). Newcastle upon Tyne: Cambridge Scholars Publishing. 61-90.

- Fox, M. 2004. "Stars in the Fasti: Ideler (1825) and Ovid's Astronomy Revisited." AJPh 125. 1: 91-133.

- Gee, E. 2001. "Cicero's Astronomy." CQ 51. 2: 520-536.

- Gill, Christopher. 2003. "The School in the Roman Imperial Period." In The Cambridge Companion to the Stoics. Brad Inwood (ed.). Cambridge: Cambridge University Press. 33-58.

- Goldstein, Bernard R., and Bowen, Alan C. 1983. "A New View of Early Greek Astronomy." Isis74. 3: 330-340.

- Hahm, David. 1977. The Origins of Stoic Cosmology. Columbus, OH: Ohio State University Press. 


\section{From Alexandria to Rome: Poetical Astronomy and Female Psychology}

- Hannah, R. 2005. Greek and Roman Calendars. London: Duckworth.

- Hannah, R. 2015. "The Roles of Observational Astronomy in Ancient Greece." Scientific Culture 1. 2: 47-56.

- Hardie, Philip R. 1989. Virgil's Aeneid: Cosmos and Imperium. Oxford: Oxford Clarendon Press.

- Irby-Massie, G. L., and Keyser, P. T. 2002. Greek Science of the Hellenistic Era: A Sourcebook. New York: Routledge.

- Jones, Alexander .1994. "The Place of Astronomy in Roman Egypt." In The Sciences in Greco-Roman Society. Timothy D. Barnes (ed.). Edmonton: Academic Printing and Publishing. 25-51.

- Jones, Alexander. 2003. "The Stoics and the Astronomical Sciences." In The Cambridge Companion to the Stoics. Brad Inwood (ed.). Cambridge: Cambridge University Press. 328-344.

- Kahn, Charles H. 1970. "On Early Greek Astronomy." JHS 90: 99-116.

- Klein, T. M. 1974. "The Role of Callimachus in the Development of the Concept of the Counter-Genre." Latomus 33: 217-231.

- Lankford, John. (ed.). 2011. History of Astronomy. An Encyclopedia. New York and London: Routledge.

- Moussas, Xenophon . 2013 a. "From Alexander to Archimedes and the Antikythera Mechanism." Proceedings of the Conference on Alexander, the Greek Cosmos-System and the Modern World Society. Thessaloniki: Academy of Institutions and Cultures, 373390. Available at: http://www.academy.edu.gr/files/prakt_alexandros/01_21_pr_al.pd f 


\section{Magda El-Nowieemy}

- Moussas, Xenophon. 2013 b. "Greek Roots of Astrophysics." The $21^{\text {st }}$ SEAC Conference on Astronomy: Mother of Civilization and Guide to the Future. Athens. 76-79.

- Moussas, Xenophon. 2013c. "Early Greek Astrophysics: The Foundations of Modern Science and Technology." American Journal of Space Science 1. 2: 129-144.

- Neugebauer, O. 1975. A History of Ancient Mathematical Astronomy. New York, Heidelberg and Berlin: Springer-Verlag.

- North, John. 1995. The Norton History of Astronomy and Cosmology. New York and London: Norton.

- O'Hara, James J. 1992. "Naming the Stars at Georgics 1. 137-38 and Fasti 5. 163-82." AJPh 113. 1: 47-61.

- Otis, Brooks. 1963. Virgil: A Study in Civilized Poetry. Oxford: Oxford Clarendon Press.

- Rihll, T. E. 1999. Greek Science. Oxford: Oxford University Press.

- Rihll, T. E. 2002. "Greek Science in Context." In Science and Mathematics in Ancient Greek Culture. C. J. Tuplin and T. E. Rihll (eds.). Oxford: Oxford University Press. 1-21.

- Segal, Charles. 2000. "Dido's Hesitation in Aeneid 4." In Why Vergil? A Collection of Interpretations. Stephanie Quinn (ed.). Wauconda, IL: Bolchanzy-Carducci Publishers. 90-100.

- Solmsen, F. 1942. "Eratosthenes as Platonist and Poet." TAPhA 73: 192213.

- Spyridis Ch., Preka-Papadema P., Gazeas K. and Kobothanasis K. 2019. "A Study of the Constellations Based on Eratosthenes' Catasterismi." Scientific Culture 5.1, 23-42. 
- Steele, M. (ed.). 2016. The Circulation of Astronomical Knowledge in the Ancient World. Leiden and Boston: Brill.

- Syropoulos, Spyros. 2010. "S-light Anomaly: Dark Brightness in Euripides' Medea." In Light and Darkness in Ancient Greek Myth and Religion. Menelaos Christopoulos et al. (eds.). Lanham, MD: Lexington Books. 77-87.

- Theodossiou, E., Manimanis, V. N. and Dimitrijevic, M. S. 2011. "The Cosmological Theories of the Pre-Socratic Greek Philosophers and Their Views for the Environment." Philosophy, Sociology, Psychology and History 10.1: 89-99.

- Wright, M. R. 1997. "Ferox virtus: Anger in Virgil's Aeneid." In The Passions in Roman Thought and Literature. S. M. Braund, C. Gill (eds.). Cambridge: Cambridge University Press. 169-184. 